\title{
ANALISIS PENGARUH JUMLAH BAGI HASIL TERHADAP JUMLAH DEPOSITO MUDĀRABAH PADA PT. BANK PANIN DUBAI SYARIAH, TBK TAHUN 2010-2017
}

\author{
Nofinawati \\ IAIN Padangsidimpuan \\ Jalan T. Rizal Nurdin Km. 4,5 Sihitang, Padangsidimpuan \\ Email :nofinawati82@gmail.com
}

\begin{abstract}
Abstrak
PT. Bank Panin Dubai Syariah, Tbk memiliki tiga jenis produk yang dikenal yaitu, penghimpunan dana, penyaluran dana, dan penyediaan jasa keuangan. Adapun salah satu produk penghimpunan dana yang dilakukan PT. Bank Panin Dubai Syariah, Tbk yaitu deposito yang menggunakan akad mudārabah. Adapun latarbelakang masalah dalam pnelitian ini adalah berdasarkan data yang diperoleh bahwa jumlahdeposito mudàrabah pada tahun 2016jumlah bagi hasil deposito muḍarabah mengalami penurunan dari tahun sebelumnya sejumlah Rp. 31.686.000.00o,- sedangkan jumlah deposito mudārabah mengalami peningkatan sejumlah Rp. 657.593.000.o0o,-. Sehingga terdapatnya fenomena yang tidak sesuai dengan teori jumlah bagi hasil terhadap jumlah deposito mudârabah dan ketidak sesuaian antara penelitian-penelitian sebelumnya. Rumusan penelitian ini adalah apakah ada pengaruh jumlah bagi hasil terhadap jumlah deposito mudārabah. Tujuan penelitian ini untuk mengetahui pengaruh jumlah bagi hasil terhadap jumlah deposito muḍ̄arabah pada PT. Bank Panin Dubai Syariah, Tbk.
\end{abstract}

\begin{abstract}
,
PT. Panin Bank Dubai Syariah, Tbk has three known types of products namely, fund raising, fund distribution, and financial service replacement. One of the funds collected by PT. Panin Dubai Syariah Bank, Tbk. A deposit that uses a muḍārabah contract. Against the background of the problem in this study is data based on the amount of cash deposits in 2016 the total profit sharing from your deposits from the previous year was Rp. 31,686,000,000, - while the number of visits to muḍārabah deposits was increased by Rp. 657,593,000,000. There are facts about phenomena that do not correspond to the number and number of discrepancies between previous studies. The formulation of this study is whether there are figures for the amount of mudianabah cash. The purpose of the study was to determine the number of results for the amount of muḍārabah deposits at PT. Panin Dubai Syariah Bank, Tbk.
\end{abstract}

Kata Kunci:Profit Sharing and Number of Mudharabah Deposits. 
ANALISIS PENGARUH JUMLAH BAGI HASIL TERHADAP

JUMLAH DEPOSITO MUD $\bar{A} R A B A H$ PADA

PT. BANK PANIN DUBAI SYARIAH, TBK

TAHUN 2010-2017

Nofinawati

\section{PENDAHULUAN / INTRODUCTION}

Bank merupakan lembaga yang di percaya oleh masyarakat dari berbagai kalangan untuk menempatkan dananya secara aman. Pada dasarnya bank memiliki peran dalam dua sisi (perantara), yaitu menghimpun dana secara langsung yang berasal dari masyarakat yang mengalami kelebihan dana (surplus unit), dan menyalurkan dana secara langsung kepada masyarakat yang mengalami kekurangan dana (defisit unit) untuk memenuhi kebutuhannya, sehingga bank disebut dengan financial depository institution (Ismail, 2014).

Bank syariah merupakan bank yang menjalankan kegiatan usahanya atau operasionalnya berdasarkan prinsip syariah. Jenis-jenis bank syariah ada tiga yaitu: Bank Umum Syariah (BUS), Unit Usaha Syariah (UUS), dan Bank Pembiayaan Rakyat Syariah (BPRS). Bank Umum Syariah (BUS) adalah bank syariah yang dalam kegiatannya memberikan jasa dalam lalu lintas pembayaran (Andri, 2009). Unit Usaha Syariah adalah bank syariah yang sistem operasionalnya masih menganut dual banking sistem (bank syariah yang operasionalnya masih di bawah naungan bank induknya yang konvensional).Bank Pembiayaan Rakyat Syariah (BPRS) merupakan bank syariah yang operasionalnya tidak boleh memberikan jasa dalam lalu lintas pembayaran (tidak boleh menawarkan produk giro).

Pada dasarnya, produk yang ditawarkan bank syariah dapat dibagi menjadi empat bagian yaitu produk penghimpunan dana (funding), produk penyaluran dana (financing), produk jasa (service) dan produk sosial. Produk penghimpunan dana di bank syariah terdiri dari produk giro, tabungan dan deposito. Prinsip syariah yang diterapkan dalam penghimpunan dana masyarakat adalah prinsip titipan dengan akad wadiah dan prinsip bagi hasil dengan akad mudārabah. Tabungan, giro dan deposito bisa menggunakan akad mudârabah (prinsip bagi hasil).Tabungan dan giro juga bisa menggunakan akad wadiah (prinsip titipan), namun deposito tidak bisa menggunakan akad wadi'ah karena deposito bersifat investasi yang bertolak belakang dengan wadiah (sifatnya titipan atau simpanan biasa). Giro diatur dalam Fatwa DSN No.01/DSNMUI/IV/2000, tabungan diatur dalam Fatwa DSN No.02/DSN-MUI/IV/2000, dan deposito diatur dalam Fatwa DSN No.03/DSN/-MUI/IV/200o.

Dalam penelitian ini, peneliti membahas tentang produk penghimpunan dana (funding) dalam bentuk deposito mudāarabah. Deposito muḍ̄arabah adalah simpanan dana dengan skema nasabah sebagai pemilik dana (șahibul māl) mempercayakan dananya untuk dikelola oleh bank (muḍārib) dengan hasil yang diperoleh dibagi antara 
pemilik dana dan bank dengan nisbah yang disepakati di awal akad. Dalam transaksi deposito muḍārabah, bank wajib memberitahukan kepada nasabah (pemilik dana) mengenai nisbah dan tata cara pemberian keuntungan serta risiko yang dapat timbul dari deposito tersebut. Deposito mudāarabah hanya bisa ditarik sesuai dengan waktu yang disepakati (Rizal, 2009).

Deposito mudāarabah merupakan salah satu produk penghimpunan dana yang paling diminati masyarakat diantara produk penghimpunan dana lainnya. Deposito muḍārabah memberikan return/imbalan berupa bagi hasil kepada nasabah atas sejumlah dana yang di investasikannya pada bank tersebut. Salah satu Bank Umum Syariah (BUS) yang menggunakan deposito muḍārabah sebagai salah satu produk penghimpunan dana (funding) adalah PT. Bank Panin Dubai Syariah, Tbk. Berikut adalah tabel jumlah depositomudāarabah pada PT. Bank Panin Dubai Syariah, Tbk periode 2010-2017.

\section{Tabel 1}

Jumlah Deposito Muḍärabah dan Jumlah Bagi Hasil

PT. Bank Panin Dubai Syariah, Tbk periode 2010-2017

( Dalam Jutaan Rupiah )

\begin{tabular}{|c|c|c|}
\hline & $\begin{array}{c}\text { Jumlah } \\
\text { DepositoMudārabah }\end{array}$ & Bagi Hasil \\
\hline 2010 & 290.505 & 9.205 \\
\hline 2011 & 393.044 & 25.376 \\
\hline 2012 & 1.006 .049 & 49.828 \\
\hline 2013 & 2.430 .835 & 120.508 \\
\hline 2014 & 4.176 .150 & 269.340 \\
\hline 2015 & 5.086 .656 & 421.249 \\
\hline 2016 & 5.744 .249 & 389.563 \\
\hline 2017 & 6.667 .851 & 480.604 \\
\hline
\end{tabular}

Sumber:www.ojk.go.id.

Berdasarkan tabel di atas dapat dijelaskan bahwa jumlah deposito muḍārabah selalu mengalami peningkatan setiap tahun, namun jumlah bagi hasilnya pada tahun 2016 mengalami penurunan dari tahun sebelumnya sejumlah Rp. 31.686.000.000,-.

Menurut teori klasik menyatakan bahwa jumlah tabungan yang dilakukan masyarakat ditentukan oleh tingkat bunga. Semakin tinggi tingkat bunga, semakin besar jumlah tabungan yang akan dilakukan masyarakat (Sadono Sukirno, 2013).Hal ini disebabkan karena konsumen melihat bahwa tingkat suku bunga simpanan yang diberikan bank konvensional ataupun tingkat bagi hasil yang diberikan bank syariah adalah sama-sama merupakan imbalan yang diberikan pihak bank kepada nasabah deposan atas dana yang diinvestasikannya di bank. Jika jumlah deposito muḍārabah 
ANALISIS PENGARUH JUMLAH BAGI HASIL TERHADAP

JUMLAH DEPOSITO MUD $\bar{A} R A B A H$ PADA

PT. BANK PANIN DUBAI SYARIAH, TBK

TAHUN 2010-2017

Nofinawati

meningkat disebabkan karena bagi hasil juga meningkat, begitu juga sebaliknya jika jumlah deposito mudārabah menurun disebabkan karena bagi hasilnya juga menurun. Mengingat tujuan nasabah mendepositokan uangnya adalah untuk mencari keuntungan yang sesuai harapan. Akan tetapi, pada kenyataannya pada tahun 2016 jumlah bagi hasil deposito mud̄ârabah mengalami penurunan dari tahun sebelumnya sejumlah Rp. 31.686.00o.ooo,-- sedangkan jumlah deposito mudârabah mengalami peningkatan sejumlah Rp. 657.593.000.000,-. Sehingga peneliti tertarik untuk mengetahui pengaruh jumlah bagi hasil terhadap jumlah deposito muḍārabah pada PT. Bank Panin Dubai Syariah, Tbk.

\section{TINJAUAN TEORITIK / LITERATURE REVIEW}

\section{Mekanisme Deposito Muḍ̄äabah}

Dalam transaksi deposito muḍārabah, bank wajib memberitahukan kepada pemilik dana mengenai nisbah dan tatacara pemberian keuntungan serta risiko yang dapat timbul dari deposito tersebut. Deposito muḍārabah hanya bisa ditarik sesuai dengan waktu yang disepakati. Berikut adalah fatwa No: 03/DSN/MUI-IV/2000 Tentang Deposito berdasarkan prinsip muḍārabah yaitu dalam transaksi ini nasabah bertindak sebagai șahibul maal atau pemilik dana, dan bank bertindak sebagai muḍārib atau pengelola dana. Dalam kapasitasnya sebagai muḍārib, bank dapat melakukan berbagai macam usaha yang tidak bertentangan dengan prinsip syari'ah dan mengembangkannya, termasuk di dalamnya mudāarabah dengan pihak lain. Modal harus dinyatakan dengan jumlahnya, dalam bentuk tunai dan bukan piutang. Pembagian keuntungan harus dinyatakan dalam bentuk nisbah dan dituangkan dalam akad pembukaan rekening. Bank sebagai mudậrib menutup biaya operasional deposito dengan menggunakan nisbah keuntungan yang menjadi haknya. Bank tidak diperkenankan untuk mengurangi nisbah keuntungan nasabah tanpa persetujuan yang bersangkutan. 
Mekanisme investasi deposito mudārabah dapat digambarkan dalam bentuk skema di bawah ini : (Ismail, 2014)

\section{Gambar 1}

Skema Deposito Muḍärabah

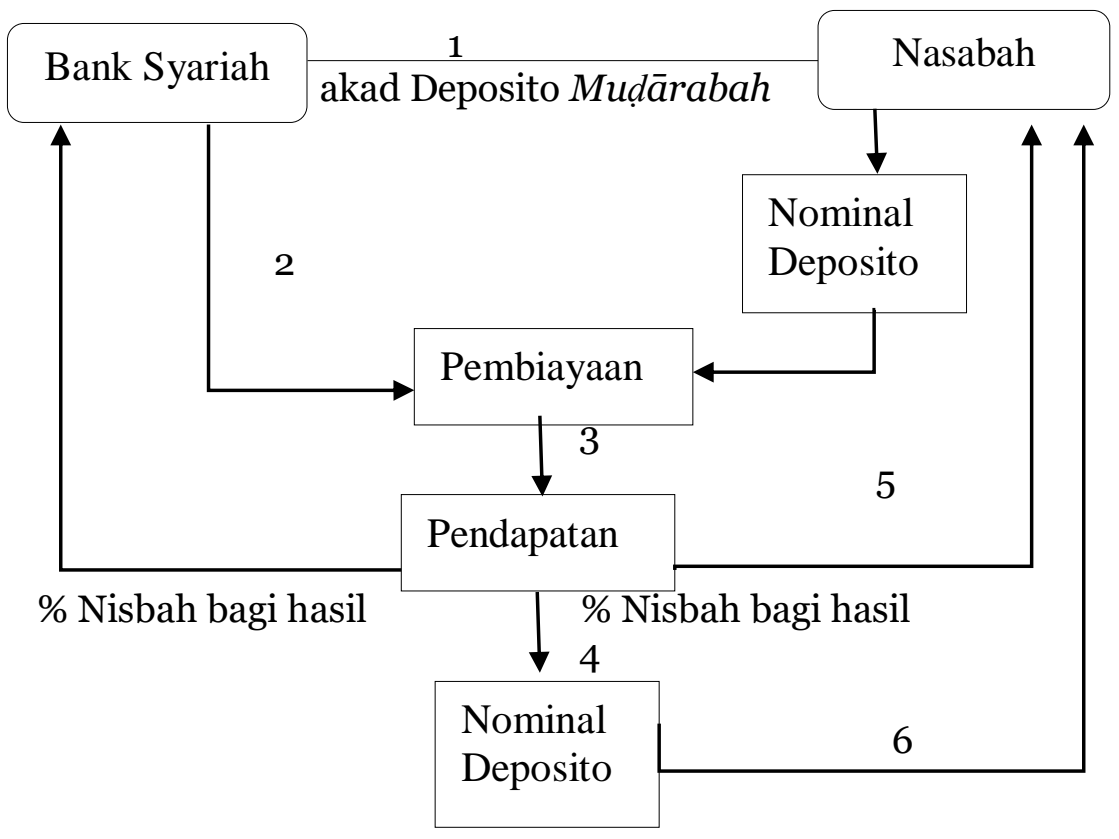

Keterangan:

Nasabah investor menempatkan dananya ke bank syariah dalam bentuk Deposito Mudārabah. Bank syariah menyalurkan dana nasabah investor dalam bentuk pembiayaan. Bank syariah memperoleh pendapatan atas penempatan dananya dalam bentuk pembiayaan. Bank syariah akan menghitung bagi hasil atas dasar revenue sharing, yaitu pembagian hasil atas dasar pendapatan sebelum dikurangi biaya. Pada tanggal valuta, yaitu tanggal penempatan deposito, nasabah akan mendapatkan bagi hasil sesuai dengan nisbah yang telah diperjanjikan. Pada saat jatuh tempo, maka dana nasabah akan dikembalikan seluruhnya.

\section{Faktor-faktor yang Mempengaruhi Deposito Muḍārabah}

Bank umum syariah menghimpun dana dari masyarakat dalam berbagai jenis produk pendanaan salah satunya adalah deposito mudărabah. Dalam menghimpun dana dapat dipengaruhi oleh beberapa faktor, diantaranya sebagai berikut: (Veithzal Rivai, 2010). Pertama, kondisi Perekonomian apabila perkembangan perekonomian maju pesat berarti berdampak positif bagi dunia usaha dan 
ANALISIS PENGARUH JUMLAH BAGI HASIL TERHADAP

JUMLAH DEPOSITO MUD $\bar{A} R A B A H$ PADA

PT. BANK PANIN DUBAI SYARIAH, TBK

TAHUN 2010-2017

Nofinawati

pendapatan masyarakat akan tumbuh sehingga akan meningkatkan minat masyarakat atau perusahaan untuk menabung dan dampaknya tabungan masyarakat akan meningkat. Demikian pula halnya bilamana perekonomian menurun, berarti berdampak pada perkembangan dunia usaha yang akan lesu, tingkat pendapatan masyarakat tidak bertambah dan bahkan menurun, yang akan berakibat penghimpunan dana bank cenderung akan menurun. Kedua, bagi hasil. Tinggi rendahnya bagi hasil yang ditawarkan bank kepada nasabah akan sangat menentukan minat nasabah untuk menyimpan uangnya pada bank tersebut. Dalam hal ini semakin tinggi tingkat bagi hasil akan menarik minat masyarakat untuk menyimpankan dananya pada bank tersebut. Ketiga, Kebijakan pemerintah seperti kebijaksanaan dalam hal fiskal, pinjaman luar negeri beserta mekanisme syaratsyarat lainnya sangat menentukan keberhasilan bank dalam menghimpun dana pula. Demikian pula kebijakan pemerintah dibidang perdagangan luar negeri (ekspor dan impor) dan lain-lain. Keempat, Kualitas layanan yang diterima dan dirasakan masyarakat (layanan prima, ramah, cermat, santun) akan memengaruhi minat masyarakat untuk menggunakan jasa bank tersebut. Kelima, Peraturan Bank Indonesia. Manajemen dana sangat dipengaruhi oleh kebijakan moneter. Pengendalian moneter bertujuan untuk menjaga jumlah uang beredar dan tingkat suku bunga sedemikian rupa sehingga dapat menunjang kegiatan usaha perekonomian masyarakat serta kemantapan neraca pembayaran.

\section{Faktor-faktor yang Mempengaruhi Bagi Hasil}

Menurut Ahmad Ifham bagi hasil adalah "suatu sistem yang meliputi pembagian hasil usaha antara pemodal dan pengelola dana"(Ahmad Ifham,2015). Bagi hasil merupakan kesepakatan dua pihak atau lebih dalam menjalankan suatu usaha dan saling berbagi hasil atas hasil usaha yang telah mereka jalankan. 
Pembagian hasil usaha di antara pihak (mitra) dalam suatu bentuk usaha kerjasama boleh didasarkan pada sistem profit and loss sharing, yakni bagi hasil yang dihitung dari pendapatan setelah di kurangi biaya pengelolaan dana atau perhitungan bagi hasil yang mendasarkan pada laba atau rugi. Boleh juga didasarkan pada sistemrevenue sharing, yakni bagi hasil yang dihitung dari total pendapatan pengelolaan dana atau perhitungan bagi hasil yang mendasarkan pada pendapatan usaha tanpa dikurangi beban usaha(Ismail, 2014).

Ada beberapa faktor yang dapat mempengaruhi bagi hasil yaitu (Ismail, 2014): Pertama, Investment rate merupakan tingkat dana atau persentase dana yang di investasikan kembali oleh bank syariah baik ke dalam pembiayaan maupun penyaluran dana lainnya. Kebijakan ini di ambil karena adanya ketentuan dari Bank Indonesia, bahwa sejumlah persentase tertentu atas dana yang dihimpun dari masyarakat, tidak boleh di investasikan, akan tetapi harus ditempatkan dalam bentuk rekening Giro Wajib Minimum (GWM) untuk menjaga lukuiditas bank syariah. Jika bank menentukan investment rate sebesar 80 persen, hal ini berarti 20 persen dari total dana dialokasikan untuk memenuhi likuiditas. Investment rate antara bank yang satu dengan bank yang lainnya bisa saja berbeda, karena besarnya tergantung kebijakan bank masing-masing. Kedua, Total dana investasi yang diterima oleh bank syariah akan memengaruhi bagi hasil yang diterima oleh nasabah investor. Total dana yang berasal dari investasi mudārabahbisa dalam bentuk tabungan mudārabah, giro mudārabahdan deposito mudārabah. Totalnya dapat dihitung dengan menggunakan saldo minimal bulanan atau saldo harian. Total dana investasi berpengaruh positif terhadap jumlah bagi hasil yang akan diterima oleh nasabah dan bank syariah itu sendiri. Ketiga, Jenis Dana. Investasi muḍārabah dalam penghimpunan dana, dapat ditawarkan dalam beberapa jenis yaitu: tabungan mud̄̄ārabah, deposito mudārabah, dan Sertifikat Investasi Mudārabah Antar bank syariah (SIMA). Setiap jenis dana investasi memiliki karakteristik yang berbeda-beda sehingga akan berpengaruh pada besarnya bagi hasil. Keempat, Nisbah merupakan persentase tertentu yang disebutkan dalam akad kerja sama usaha (mud̄ârabahdan musyarakah) yang telah disepakati antara bank dan nasabah investor. Salah satu ciri mudārabahadalah nisbah harus ditentukan dan disetujui pada awal perjanjian. Nisbah antara satu bank dan bank lainnya dapat berbeda, juga dapat berbeda dari waktu ke waktu dalam satu bank, misalnya deposito 1 bulan, 3 bulan, 6 bulan, dan 12 
ANALISIS PENGARUH JUMLAH BAGI HASIL TERHADAP

JUMLAH DEPOSITO MUD $\bar{A} R A B A H$ PADA

PT. BANK PANIN DUBAI SYARIAH, TBK

TAHUN 2010-2017

Nofinawati

bulan. Kelima, Metode Perhitungan Bagi Hasil. Jumlah bagi hasil akan berbeda berdasarkan pada sistem perhitungan bagi hasil yang digunakan oleh bank syariah.Sistem perhitungan jumlah bagi hasil dihitung dengan menggunakan sistem revenue sharing dan bagi hasil dengan menggunakan sistemprofit and loss sharing. Keenam, Kebijakan Akuntansi. Kebijakan akuntansi akan berpengaruh pada besarnya bagi hasil. Beberapa kebijakan akuntansi yang akan memengaruhi bagi hasil antara lain penyusutan dan sistem pengakuan dan perhitungan pendapatan (acrual basic or cash basic).

\section{Hubungan Bagi Hasil dengan Jumlah Deposito Muḍārabah}

Jumlah deposito mudāarabah merupakan banyaknya dana investasi yang ditempatkan oleh nasabah yang tidak bertentangan dengan prinsip syariah dan penarikannya hanya dapat dilakukan pada waktu tertentu. Prinsip bagi hasil (profit sharing) merupakan karakteristik dasar perbankan syariah. Karena prinsip bagi hasil diterapkan dalam kegiatan penghimpunan dana dan kegiatan penyaluran dana. Bagi hasil meningkat maka jumlah deposito juga meningkat begitu sebaliknya, jika bagi hasil turun maka jumlah deposito juga turun, oleh karna itu, antara bagi hasil dengan jumlah deposito mudāabah memiliki hubungan yang positif. Penelitian Suratman menunjukkan bahwa "jumlah bagi hasil deposito muḍārabah berpengaruh signifikan terhadap jumlah deposito muḍārabah". Penelitian Rusliza rmenunjukkan bahwa "tingkat bagi hasil deposito mudārabah berpengaruh positif terhadap pertumbuhan deposito muḍārabah”. Penelitian Evi Natalia menunjukkan bahwa "tingkat bagi hasil deposito bank syariah berpengaruh terhadap jumlah simpanan deposito muḍārabah”. Dari hasil penelitian di atas, peneliti menyimpulkan bahwa bagi hasil ada pengaruh terhadap jumlah deposito muḍārabah.

\section{METODE PENELITIAN / METHODS}

\section{JenisPenelitian}

Penelitian ini adalah field research dengan jenis penelitian kuantitatif. Penelitian kuantitatif adalah suatu pendekatan yang banyak dituntut menggunakan angka, mulai dari pengumpulan data, penafsiran terhadap data, serta penampilan dari hasilnya (Suharsimi Arikunto, 2010). Menurut metodenya, penelitian ini menggunakan metode asosiatif. Penelitian asosiatif adalah penelitian yang bertujuan 
untuk mengetahui pengaruh ataupun juga hubungan antara dua variabel atau lebih (Sugiyono, 2006).

\section{Sumber Data}

Sumber data yang digunakan dalam penelitian ini adalah data sekunder yaitu data bagi hasil dan simpanan deposito mudârabah yang di akses melalui situs www.ojk.go.id. Menurut Dermawan Wibisono data sekunder adalah "data yang di dapat dan disimpan oleh orang lain yang biasanya merupakan data masalalu atau historical”(Dermawan, 2002).

\section{TeknikPengumpul Data}

Adapun teknik pengumpulan data yang dilakukan dalam penelitian ini adalah metode kepustakaan dan dokumentasi. Studi kepustakaan yang digunakan dalam penelitian ini adalah dengan sumber buku-buku, jurnal dan skripsi yang membahas tentang jumlah bagi hasil dan jumlah deposito muḍārabah.

Menurut Abdurrahman Fathoni, dokumentasi adalah "teknik pengumpulan data dengan mempelajari catatan-catatan" (Abdurrahman Fathoni, 2011). Data dokumentasi yang digunakan dalam penelitian ini adalah data laporan triwulan jumlah bagi hasil dan jumlah deposito muḍārabah pada PT. Bank Panin Dubai Syariah, Tbk periode 2010-2017.

\section{Teknik Analisa Data}

Metode analisis data yang digunakan dalam penelitian ini adalah metode analisis data dengan bantuan Software Statistical Product Service Solution (SPSS VERSI 24). Teknik analisis data yang dilakukan dalam penelitian ini adalah:analisis deskriptif, uji normalitas, uji linearitas, uji hipotesis dan analisis regresi sederhana.

$$
\begin{aligned}
& \mathrm{Y}=\mathrm{a}+\mathrm{bX} \quad \mathrm{JDM}=\mathrm{a}+\mathrm{bBH} \\
& \text { Keterangan: } \\
& \mathrm{Y}=\text { Jumlah Depositomudārabah (JDM) } \\
& \mathrm{a}=\text { konstanta } \\
& \mathrm{b}=\text { koefisien regresi } \\
& \mathrm{X}=\text { Bagi Hasil (BH) }
\end{aligned}
$$

\section{HASIL DAN PEMBAHASAN/DISCUSSION}

\section{Deskripsi Data Penelitian}

Data penelitian ini diperoleh dari laporan keuangan publikasi triwulanan PT. Bank Panin Dubai Syariah, Tbk periode 2010 triwulan ke II sampai triwulan ke IV 2017 
yang di akses dari statistik perbankan syariah melalui website $\underline{w w w . o j k . g o . i d}$. Dalam hal ini peneliti akan memaparkan perolehan data yang berhubungan dengan data tentang variabel penelitian, diantaranya yaitu bagi hasil dan jumlah deposito mudāarabah dari periode 2010 triwulan ke II sampai 2017 triwulan ke IV. Untuk masing-masing variabel dapat diuraikan sebagai berikut.

Jumlah Deposito Mudārabah adalah banyaknya simpanan masyarakat yang disimpan kepada bank syariah dapat berupa rupiah ataupun valuta asing dimana penarikannya hanya dapat dilakukan berdasarkan jangka waktu yang telah di tetapkan dan disepakati antara nasabah dengan pihak bank syariah. Berikut adalah data jumlah deposito muḍārabah triwulan dalam bentuk grafik:

Grafik.1

Jumlah Deposito Mudèrabah

Pada PT. Bank Panin Dubai Syariah, Tbk (Jutaan Rupiah)

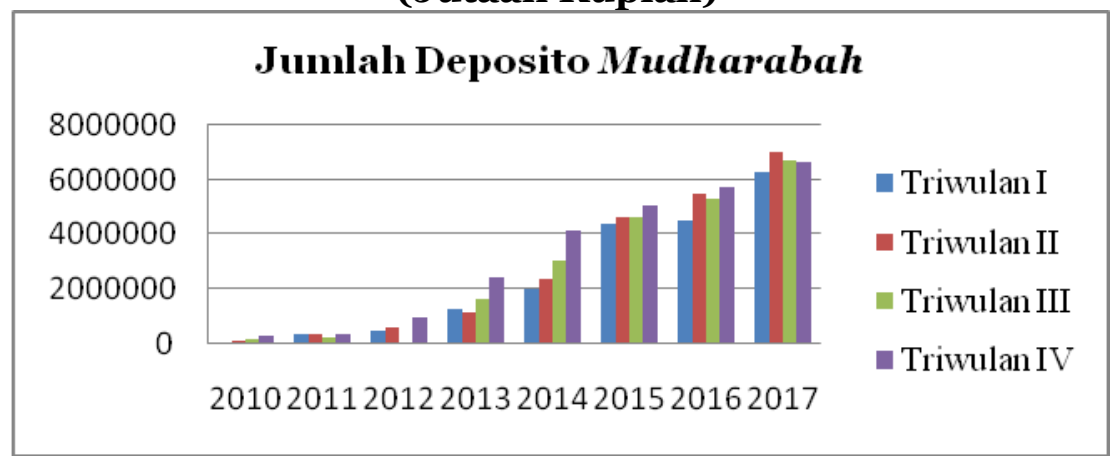

Sumber: www.ojk.go.id

Pada grafik di atas dapat dilihat bahwa data jumlah deposito muḍārabah mengalami fluktuasi, yaitu pada tahun 2011 triwulan ke III sebesar 0,39 persen. Pada tahun 2013 triwulan ke II mengalami penurunan kembali sebesar 0,06 persen dan pada tahun 2014 triwulan I kembali mengalami penurunan sebesar 0,17 persen. Pada tahun 2015 triwulan ke III mengalami penurunan sebesar 0,005 persen, pada tahun 2016 triwulan ke I mengalami penurunan sebesar 0,12 persen. Pada tahun 2017 triwulan ke III mengalami penurunan sebesar 0,04 persen dan kembali mengalami penurunan pada triwulan ke IV sebesar 0,005 persen. 


\section{Grafik.2}

Bagi Hasil Pada PT. Bank Panin Dubai Syariah, Tbk (Jutaan Rupiah)

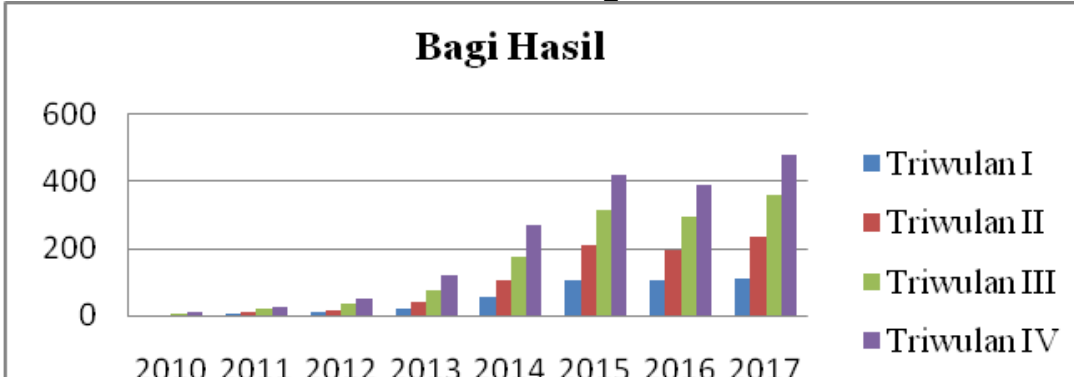

20102011201220132014201520162017

Sumber: www.ojk.go.id

Pada grafik di atas dapat dilihat bahwa data jumlah bagi hasil mengalami fluktuasi, yaitu pada tahun 2011 triwulan ke I mengalami penurunan dari triwulan sebelumnya sebesar 0,33 persen. Pada tahun 2012 triwulan ke I mengalami penurunan sebesar 0,68 persen. Tahun 2013 kembali mengalami penurunan pada triwulan ke I sebesar 0,58 persen, tahun 2014 triwulan ke I penurunannya sebesar 0,54 persen. Pada tahun 2015 triwulan ke I mengalami penurunan sebesar 0,60 persen, tahun 2016 triwulan ke I kembali mengalami penurunan sebesar 0,75 persen. Pada tahun 2017 triwulan ke I bagi hasil kembali mengalami penurunan sebesar 0,71 persen.

\section{Hasil Analisis}

Data yang diperoleh oleh peneliti masih berupa data mentah, maka dalam hal ini data diubah ke dalam bentuk LN (Logaritma Natural) dan RES (Unstandardized Residual) untuk memudahkan peneliti menguji dan menganalisis data.

Statistik Deskriptif, pada analisis deskriptif ini, akan dikemukakan cara-cara penyajian data, dengan tabel biasa maupun distribusi frekuensi, grafik, garis maupun batang, diagram lingkaran, histogram, serta penjelas kelompok melalui modus, median, mean, serta variasi kelompok melalui rentang dan simpang baku dapat dilihat pada tabel dibawah ini:

Tabel 2

Hasil Uji Statistik Deskriptif

Descriptive Statistics

\begin{tabular}{|l|c|c|c|c|c|}
\hline \multicolumn{7}{|c|}{ Descriptive Statistics } \\
\hline & $\mathrm{N}$ & Minimum & Maximum & Mean & Std. Deviation \\
\hline $\begin{array}{c}\text { jumlah deposito } \\
\text { muḍārabah }\end{array}$ & 31 & 93144.00 & 7033508.00 & 2883963.7420 & 2386772.35700 \\
\hline jumlah bagi hasil & 31 & 1282.00 & 480604.00 & 128896.8710 & 141637.16190 \\
\hline Valid N (listwise) & 31 & & & & \\
\hline
\end{tabular}

Sumber: Hasil Output SPSS Versi 24 
ANALISIS PENGARUH JUMLAH BAGI HASIL TERHADAP

JUMLAH DEPOSITO MUD $\bar{A} R A B A H$ PADA

PT. BANK PANIN DUBAI SYARIAH, TBK

TAHUN 2010-2017

Nofinawati

Berdasarkan tabel 2 di atas diketahui bahwa jumlah sampel (N) sebanyak 31. Nilai minimum variabel jumlah deposito muḍārabah sebesar 93144,00 dan nilai minimum variabel jumlah bagi hasil sebesar 1282,oo. Untuk nilai maksimum variabel jumlah deposito muḍārabah sebesar 7033508,00 dan nilai maksimum variabel jumlah bagi hasil sebesar 480604,o0. Rata-rata variabel jumlah deposito mud̄ārabah sebesar 2849250,1610, dan untuk rata-rata variabel jumlah bagi hasil sebesar 128896,8710. Untuk nilai standar variabel jumlah deposito mudāarabah sebesar 2423786,86300 dan untuk nilai standar variabel jumlah bagi hasil sebesar 141637,16190 .

Analisis regresi sederhana merupakan analisis regresi dua variabel, yaitu suatu model dimana hanya ada satu variabel bebas (independent) dan satu variabel tidak bebas/terikat (dependent) yang dinyatakan sebagai fungsi linear. Analisis regresi digunakan untuk memprediksi bagaimana perubahan variabel dependen bila variabel independen diubah nilainya.

Tabel IV.4

Analisis Regresi Sederhana

\begin{tabular}{|c|c|c|c|c|c|c|}
\hline \multicolumn{7}{|c|}{ Coefficients $^{\mathbf{a}}$} \\
\hline & \multirow{2}{*}{ Model } & \multicolumn{2}{|c|}{$\begin{array}{l}\text { Unstandardized } \\
\text { Coefficients }\end{array}$} & \multirow{2}{*}{$\begin{array}{c}\begin{array}{c}\text { Standardized } \\
\text { Coefficients }\end{array} \\
\text { Beta } \\
\end{array}$} & \multirow[b]{2}{*}{$\mathrm{t}$} & \multirow[b]{2}{*}{ Sig. } \\
\hline & & $\mathrm{B}$ & Std. Error & & & \\
\hline \multirow[t]{2}{*}{1} & (Constant) & 4.806 & .774 & & 6.212 & .000 \\
\hline & JBH & .859 & .070 & .915 & 12.213 & .000 \\
\hline
\end{tabular}

Berdasarkan hasil pengukuran regresi yang ditunjukkan pada tabel di atas, maka model persamaannya adalah sebagai berikut:

$\mathrm{JDM}=\mathrm{a}+\mathrm{bJBH}$

$\mathrm{JDM}=4,806+0,859 \mathrm{JBH}$

Penjelasan persamaan di atas adalah sebagai berikut:

Pertama, konstanta sebesar 4,806 menyatakan bahwa jika jumlah bagi hasil diasumsikan nilainya adalah o maka deposito mudārabah nilainya Rp. 4.806.ooo,. Kedua, angka koefisien regresi variabel jumlahbagi hasil bernilai o,859 menyatakan bahwa setiap terjadi kenaikan jumlah bagi hasil sebesar Rp 1.000.00o makajumlah deposito muḍārabah mengalami peningkatan sebesar Rp 859.000. 


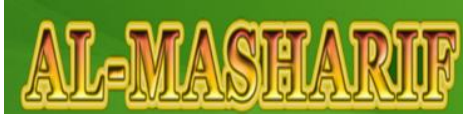

JURNAL IMUURKONOMIDAN KBISTAMAN
Al-Masharif: Jurnal Ilmu Ekonomi dan Keislaman

Volume 6 Nomor 1 Ed. Januari-Juni 2018 : hal. 87-102

p-ISSN: 2356-4628 e-ISSN : 2579-8650

\section{Uji Hipotesis}

Uji Koefisien Determinasi ( $\left.\mathrm{R}^{2}\right)$

Koefisien Determinasi $\left(\mathrm{R}^{2}\right)$ pada intinya mengukur seberapa jauh kemampuan model dalam menerangkan variasi variabel terikat. Semakin besar nilai $\mathrm{R}^{2}$, maka ketepatannya dikatakan semakin baik.

Tabel IV. 5

Uji Koefisien Determinasi

\begin{tabular}{|c|c|c|c|c|}
\hline \multicolumn{5}{|c|}{ Model Summary $^{\mathbf{b}}$} \\
\hline Model & $\mathrm{R}$ & R Square & $\begin{array}{c}\text { Adjusted R } \\
\text { Square }\end{array}$ & $\begin{array}{c}\text { Std. Error of } \\
\text { the Estimate }\end{array}$ \\
\hline 1 & $.915^{\mathrm{a}}$ & .837 & .832 & .62331 \\
\hline
\end{tabular}

Sumber: Hasil Output SPSS Versi 24, data di olah

Berdasarkan tabel IV.5 diketahui bahwa nilai $R$ Square sebesar 0,837 atau sama dengan $83,7 \%$. Berarti $83,7 \%$ variabel jumlah bagi hasil mempengaruhi jumlah deposito mudārabahdan sisanya 16,3\% dipengaruhi oleh variabel lain seperti kondisi perekonomian, kebijakan pemerintah, kualitas layanan dan peraturan BI yang tidak dimasukkan dalam penelitian ini.

Uji Koefisien Regresi Secara Parsial (Uji t), uji ini digunakan untuk mengetahui apakah variabel independen berpengaruh secara signifikan terhadap variabel dependen, maka digunakan tingkat signifikan sebesar $5 \%$ atau 0,05. Adapun variabel independen yaitu jumlah bagi hasil dan variabel dependen jumlah deposito muḍārabah.

Tabel IV.6

Uji Koefisien Regresi Secara Parsial (Uji t)

\begin{tabular}{|c|c|c|c|c|c|c|}
\hline \multicolumn{7}{|c|}{ Coefficients ${ }^{a}$} \\
\hline & \multirow{2}{*}{ Model } & \multicolumn{2}{|c|}{$\begin{array}{l}\text { Unstandardized } \\
\text { Coefficients }\end{array}$} & \multirow{2}{*}{$\begin{array}{c}\begin{array}{c}\text { Standardized } \\
\text { Coefficients }\end{array} \\
\text { Beta }\end{array}$} & \multirow[t]{2}{*}{$\mathrm{T}$} & \multirow{2}{*}{ Sig. } \\
\hline & & B & Std. Error & & & \\
\hline \multirow[t]{2}{*}{1} & (Constant) & 4.806 & .774 & & 6.212 & .000 \\
\hline & JBH & .859 & .070 & .915 & 12.213 & .000 \\
\hline
\end{tabular}

Sumber: Hasil Output SPSS Versi 24

Untuk mengetahui apakah koefisien regresi signifikan atau tidak maka digunakan uji t. Menguji signifikan variabel jumlah bagi hasil berdasarkan tabel di atas adalah nilai $t_{\text {hitung }}$ sebesar 12,213 sedangkan tabel 1,692. Untuk koefisien regresi $t_{\text {itung }}$ lebih besar dari $t_{\text {tabel }}(12,213>1,692)$, maka $\mathrm{H}_{\mathrm{a}}$ diterima dan $\mathrm{H}_{\mathrm{o}}$ ditolak. Artinya variabel jumlah bagi hasil berpengaruh signifikan terhadap jumlah deposito mud̄ārabahpada PT. Bank Panin Dubai Syariah, Tbk. 
ANALISIS PENGARUH JUMLAH BAGI HASIL TERHADAP

JUMLAH DEPOSITO MUD $\bar{A} R A B A H$ PADA

PT. BANK PANIN DUBAI SYARIAH, TBK

TAHUN 2010-2017

Nofinawati

\section{Pembahasan Hasil Penelitian}

Penelitian ini bertujuan untuk mengetahui apakah ada pengaruh jumlah bagi hasil terhadap jumlah deposito muḍ̄arabah pada PT. Bank Panin Dubai Syariah, Tbk. Berdasarkan pengolahan data yang dilakukan dengan menggunakan program SPSS Versi 24, maka diperoleh hasil thitung variabel jumlah bagi hasil sebesar 12,213 dan $t_{\text {tabel }}$ diperoleh sebesar 1,692. Jadi $t_{h i t u n g}>t_{\text {tabel }}$ atau 12,213 $>1,692$ artinya $H_{a}$ diterima sehingga jumlah bagi hasil memiliki pengaruh signifikan terhadap jumlah deposito mudāarabah. Hal ini menunjukkan bahwa variabel jumlah bagi hasil memiliki pengaruh positif terhadap jumlah deposito mudārabah. Apabila semakin tinggi jumlah bagi hasil maka semakin tinggi pula jumlah deposito mudārabah pada PT. Bank Panin Dubai Syariah, Tbk. Begitu pula sebaliknya, apabila semakin rendah jumlah bagi hasil maka jumlah deposito mudārabah juga akan rendah pada PT. Bank Panin Dubai Syariah, Tbk. Terlihat dari penelitian ini dimana terbukti bahwa jumlah bagi hasil berpengaruh positif terhadap jumlah deposito mudārabah dimana hasil $\mathrm{R}^{2}$ yang diperoleh menjelaskan bahwa nilai R square (koefisien determinasi)dalam tabel sebesar 0,837 atau sama dengan 83,7\%. Berarti persentase sumbangan pengaruh jumlah bagi hasil terhadap jumlah deposito mudărabah sebesar $83,7 \%$. Sedangkan sisanya sebesar $16,3 \%$ dipengaruhi atau dijelaskan oleh variabel lain seperti kondisi perekonomian, kebijakan pemerintah, kualitas layanan dan peraturan Blyang tidak dimasukkan dalam model penelitian ini.

Hasil penelitian ini sejalan dengan penelitian Suratman yang berjudul pengaruh jumlah bagi hasil deposito muḍārabah, tingkat imbalan SBIS, suku bunga simpanan berjangka 1 bulan, dan inflasi terhadap jumlah deposito mud̄ārabah (studi kasus PT Bank Syariah Mandiri tahun 2007-2011) menyatakan hasil analisis menunjukkan bahwa secara parsial jumlah bagi hasil deposito mudārabah berpengaruh signifikan terhadap jumlah deposito muḍarabah dengan nilai thitung $>$ $t_{\text {tabel }}$ atau $8,378>1,671$. Sedangkan penelitian ini hasil $t_{\text {hitung variabel bagi hasil }}$ sebesar 12,213 dan $t_{\text {tabel }}$ diperoleh sebesar 1,692. Jadi $t_{\text {hitung }}>t_{\text {tabel }}$ atau 12,213 $>1,692$ artinya $\mathrm{H}_{\mathrm{a}}$ diterima sehingga bagi hasil memiliki pengaruh signifikan terhadap jumlah deposito mudārabah. 
Hasil penelitian Ruslizar dengan judul pengaruh tingkat bagi hasil deposito mud̄ārabah, financing to deposit ratio, dan suku bunga deposito terhadap pertumbuhan deposito mudārabahpada Bank Umum Syariah (BUS) di Indonesia mengatakan bahwa tingkat bagi hasil deposito mudārabah secara parsial berpengaruh positif terhadap pertumbuhan deposito mudārabah .

\section{Keterbatasan Penelitan}

Pelaksanaan penelitian ini dilakukan dengan langkah-langkah yang disusun sedemikian rupa agar rencana dan hasil yang diperoleh berjalan sesuai dengan apa yang diharapkan. Namun, untuk memperoleh hasil yang optimal tentu sulit, dalam pelaksanaan penelitian ini terdapat beberapa keterbatasan. Beberapa keterbatasan yang dihadapi peneliti memerlukan perbaikan dan pengembangan dalam penelitanpenelitian berikutnya. Keterbatasan-keterbatasan dalam penelitian ini adalah: objek yang digunakan untuk di analisa pada PT. Bank Panin Dubai Syariah, Tbk terbatas dengan jumlah sampel sebanyak 31. Variabel independen yang digunakan dalam penelitian ini hanya menggunakan 1 variabel yaitu jumlah bagi hasil. Variabel independen dalam penelitian ini hanya dibatasi pada jumlah bagi hasil yang menyebabkan terdapat kemungkinan faktor-faktor lain yang mempengaruhi jumlah deposito mudārabah pada PT. Bank Panin Dubai Syariah, Tbk.

\section{KESIMPULAN/CONCLUSION}

Berdasarkan hasil penelitian di atas dapat diketahui bahwa jumlah bagi hasil berpengaruh terhadap jumlah deposito mudārabahpada PT. Bank Panin Dubai Syariah. Nilai $\mathrm{R}^{2}$ sebesar 0,837 , artinya persentase sumbangan pengaruh jumlah bagi hasil terhadap jumlah deposito muḍ̄arabah yaitu sebesar 83,7\% sementara 16,3\% dipengaruhi oleh variabel lain yang tidak dimasukkan dalam penelitian ini. Kemudian, berdasarkan uji signifikansi parsial (uji t), jumlah bagi hasil berpengaruh positif terhadap jumlah deposito mudārabah yaitu dengan nilai $t_{\text {hitung }}>t_{\text {tabel }}$ atau $12,213>1,692$.

\section{DAFTAR PUSTAKA / REFERENCES}

Abdurrahman Fathoni, 2011, Metodologi Penelitian \& Teknik Penyusunan Skripsi, Jakarta, Rineka Cipta.

Ahmad Ifham, 2015, Ini Lho Bank Syariah: Memahami Bank Syariah Dengan Mudah, Jakarta: PT Gramedia Pustaka Utama. 
ANALISIS PENGARUH JUMLAH BAGI HASIL TERHADAP

JUMLAH DEPOSITO MUD $\bar{A} R A B A H$ PADA

PT. BANK PANIN DUBAI SYARIAH, TBK

TAHUN 2010-2017

Nofinawati

Andri Soemitra, 2009, Bank dan Lembaga Keuangan Syariah, Jakarta: Kencana.

Ascarya, 2011, Akad dan Produk Bank Syariah, Jakarta: Rajawali Pers.

Wibisono,Dermawan,2002, Riset Bisnis, Jakarta: Gramedia Pustaka Utama.

Priyanto, Dwi, 2008, Mandiri Belajar SPSS, Yogyakarta: Media Kem.

Irham, Fahmi, 2015, Manajemen Perbankan: Konvensional dan Syariah, Jakarta: Mitra Wacana Media.

Ismail, 2014, Perbankan Syariah, Jakarta: Kencana.

Kasmir, 2007, Bank \& Lembaga Keuangan Lainnya, Jakarta: PT Raja Grafindo Persada.

Kuncoro, Mudrajad, 2009, Metode Riset Untuk Bisnis dan Ekonomi, Jakarta: Erlangga.

Syafi'I, Muhammad, Antonio, 2001, Bank Syariah: Dari Teori ke Praktik, Jakarta: Gema Insani Perss.

Firdaus, Muhammada, 2011, Ekonometrika Suatu Pendekatan Aplikatif, Jakarta: PT Bumi Aksara.

Yaya, Rizal, 2009, Akuntansi Perbankan Syariah, Jakarta: Salemba Empat.

Sukirno, Sadono, 2013, Mikro Ekonomi Teori Pengantar - Edisi Ketiga, Jakarta: PT Raja Grafindo Persada.

Sugiyono, 2012, Metode Penelitian Bisnis Pendekatan Kuantitatif, Kualitatif dan R\&D, Bandung: Alfabeta Bandung. , 2006, Metode Penelitian Bisnis, Bandung: Alfabeta.

Arikunto, Suharsimi, 2010, Prosedur Penelitian Suatu Pendekatan Praktek, Jakarta: Rineka Cipta.

Rivai, Veithzal, 2010, Islamic Banking: Sebuah Teori, Konsep, dan Aplikasi, Jakarta: Bumi Aksara.

Evi Natalia, 2014, Pengaruh Tingkat Bagi Hasil Deposito Bank Syariah dan Suku Bunga Deposito Bank Umum Terhadap Jumlah Simpanan Deposito Mudārabah(studi pada PT. Bank Syariah Mandiri Periode 2009-2012), dalam Jurnal Administrasi Bisnis, Malang, Jurusan Administrasi Bisnis, Universitas Brawijaya.

Al Farizi, Fauzan,2016, "Pengaruh Inflasi, Suku Bunga, Likuiditas dan Bagi Hasil Fakultas Ilmu Administrasi Terhadap Deposito Muḍ̄arabah)",dalam Jurnal Ilmu dan Riset Akuntansi, Volume 5, No.4, April.

Timami, Fatibut, Muhammad,2013, "Pengaruh dan Manfaat Bagi Hasil Terhadap Jumlah Simpanan Mudāarabah Bank Syariah Mandiri di Indonesia”, dalam Jurnal Pendidikan Ekonomi, Semarang, Universitas Semarang. 